\title{
PRAGMATICS ANALYSIS OF ENGLISH SLOGANS USED IN
}

\section{MOTORCYCLEADVERTISEMENT}

\author{
WISNU WARDANI
}

UniversitasPendidikan Indonesia, Indonesia

\begin{abstract}
One of the ways to promote certain products is through advertisement. Advertisements may appear in brochures, magazines, newspaper, radio, television and also internet. The interesting thing from advertisements is the language they use. They frequently use persuasive language in order to attract the consumers or buyers. One of the ways to persuade the consumers or buyers is using interesting slogans. The interesting slogan will be easily remembered by the consumers or buyers. The aim of this study was to analyze the language used in the advertisement of motorcycle particularly its English slogans from pragmatics view focusing on certain features of pragmatics namely, linguistic form, speech acts, and conversational maxims. The data collected in this study were 23 English slogans found in motorcycle advertisements. The design of the study was qualitative descriptive. In analyzing the speech acts features the study focuses on 5 types of speech acts, they are representatives, commissives, directives, declaratives, and expressive. The study found that there were two linguistics forms used in the slogans, they were sentences and phrases. Two sentences appeared in declarative forms. Three kinds of phrases were found. By the speech acts analyzing the study found there were 15 utterances belonged to representatives, 1 utterance included in commissives, 1 utterance followed to expressive, and 6 utterances belonged to directives. All slogans belonged to quantity and quality maxims at once.
\end{abstract}

KEYWORDS:Conversational Maxim, Linguistic Form, Pragmatics, Slogans \& Speech Acts

Received: Apr16, 2018; Accepted: May 06, 2018; Published: May19, 2018; PaperId.: IJELJUN20188

\section{INTRODUCTION}

Language is one of the most essentialaspectsof human life. People can express or deliver what they want by using the language. It seems that there will be no well-established human interaction or communication if there is no language. It looks that where there is human being take place then there will be language that is why language is universal. Language is considered as a tool of communication, its function does not only to share ideas, to convey meaning or to deliver the willingness in social interaction but also it is used for more intentions.Moreover language also appear in the symbol. That such symbol is interpreted by the same way by the people in certain speech community or society. There is also a language which called as sign language that is usually used by people who suffering hard-hearing or hearing impairment. Whatever the type of language emerges, it can be used to establish a good relationship among the members.It may be right that language is regarded as the most significant means of communication among the individuals whether it is in the same community or different community. It can be said that language and communication are two things that cannot be separated because language is considered as a mean of communication and the result of the emerging of the language is communication. 
In addition, we may say that to survive human need communicate to others, to have interaction with others, to make a transaction, etc. There will be some information conveyed when people are making communication.It is very important to be able to understand the conversation or what the speakeractually means. As the consequent when the hearer or addressee does not catch or get what actually means by the speaker is then the message will not be delivered successfully. Whenever or wherever language is used, there will bea speaker and his purpose or intention,and it seems that it is more frequently than not, the ultimate message is concealed behind the literal meaning of what speaker said.The discrepancy between the literal meaning of a sentence and what actually want to convey by a speaker, is studied under the broad name of pragmatics which is common in everyday life. In non-literal uses of sentences, the idea that is conveyed is not the same as the meanings of the words (Hofmann, 1995).

Language is the main means for people to communicate. The use of language seems to be governed by the situations or conditions of societyfor various. These conditions determine the users' access to, and control of their communicative means.Later, pragmatics is the study of the condition of human languageuses as these are determined by the context of society (Mey, 1994). One of the communication sorts is verbal communication. Verbal communication always improve by the time goes (science and technology) because it has tide relationship with the society who uses it to interact with the social environment.

The competition in trade worlds grows fast in line with the economic development. They try to attract more consumers.It is very common that producers or industries compete with each other for attracting customers and buyer's attention. It can be seen that every producers and industries create an advertisement to promote their products. This advertisement is used to introduce their products to customers and buyers. They hope that they will control the market share by winning the market competition through advertisement.It is noticeable that advertisement plays the role as one of important tools in marketing and business world.

By the explanation above, it can be inferred that advertisement seems to be an effective way to promote some products or services and increase the market share as well. Many media can be used as places by producers or industries to share or deliver the advertisement. Media such as newspaper, magazines, radios, and television are places where producers or industries can put their advertisements and each of those media has its own characteristics.Advertisements in the newspaper may appear in form of written-only and advertisement uses image ant words on it. They are usually not so big; they may only consist of few columns. In the magazines, the advertisement may consist of one full page of the magazine. They have also colorful pictures. Meanwhile, in radios, the listener can hear the voice of announcers promoting the product, whileadvertisements in television are more interesting. The television audiences can see the products and the models promoting the products.

An advertisement can be a mean of marketing and communicating which provides information of goods, ideas, and services. An advertisement is alsonon-personal; it means that sellers and buyers are not face to face. People are influenced to do act after they are persuaded through the advertisement. By persuading the audiences through advertisement, producers or industries hope that they can attract consumers as many as possible and eventually it provides the profitable return on their investment.Interestingly, sometimes the utterance or sentence that isdelivered by advertisements is not clear.They may not always straight to the point. The utterance or sentence usedmakes the readers wonder what it means actually. By their curiosity, they attempt to understand the message based on their own interpretations which can be so various.In fact, it may be very complicated becausewhat the advertiser has written can beso 
open formisinterpretation. Departing from the phenomenon, the writer is interested in discussing the pragmatic features of an advertisement particularly relate to the Speech act, conversational Maxims, and Politeness.

Through this study, the writer is interested in analyzing the pragmatics features of slogans in motorcycle advertisement. The advertisement slogans of motorcycle products commonly use interesting utterances. The advertisements which are going to be analyzed are slogans used in a motorcycle. The limitation of this study is that it focuses on the advertisement of motorcycle produced by Honda which appears in television. The reason of choosing these advertisements is because they have interesting utterances and very open interpretation as well. The objective of this study is to analyze pragmatics features of utterances use in slogans of motorcycle advertisement from speech act, conversational maxims, and politeness elements.

Slogan is a memorable motto, or phrase used in political, commercial, religious and another context as a repetitive expression of an idea or purpose. Urdang and Robbins (1984: 18) define that slogan is a group of words that promise a reward in a dramatic way which is easy to read, easy to say, and easy to remember. Slogan used to illustrate a product and the languages of slogan represent the particular product. The advertisers always choose attractive words although the words are not familiar with the customers. It is often encountered when the people reading a slogan in a car advertisement.

Pragmatics as one of the linguistics branches is the study of how to get morecommunicated than what it is said (Yule, 1996). Pragmatics is the study of those relations between language and context grammaticalized, or encoded in the structure of a language (Levinson, 1983). "Pragmatics is the science of language seen in relation to its users. That is to say, not the science of language in its own right, or the science of language as seen and studied by the linguists, or the science of language as the expressions of out- desire to play schoolmarm, but the science of language as it is used by real, live people, for their own purposes and within their limitations and affordances" (Mey, 1994: 5). Pragmatics studies how people comprehend and produce a communicative act or speech act in a concrete speech situation which is usually a conversation or spoken language. It distinguishes two purposes or meanings in each utterance or communicative act of verbal communication. One is the informative purpose or the sentence meaning, and the other is the communicative purpose or speaker meaning.

Regarding the meaning of the utterances, Thomas (1995) says that pragmatics deals with the negotiation of meaning between speaker and listener, the context of the utterance, the meaning potential of an utterance. Moreover, the difference between denotation and reference leads into focus another significant aspect of meaning - the context in which an expression is used. We have to take as considerations that the fact the same expression used in a different context may have the same meaning in some respects but different in other respects (Gregory, 2000). Verschueren (1999) suggests four traditional extents of pragmatics; those are deixis, speech acts, implicit meaning, and conversation, as well as politeness and argumentation.Grice (1989) argues that in ordinary conversation, speakers and hearers share a cooperative principle. Speakers construct their utterances so they can be understood by hearers. The principle can be explained by four underlying rules or maxims. (David Crystal calls themconversational maxims. They are also sometimes named Grice's or Griceanmaxims). They are the maxims of quality, quantity, relevance and manner.

- Quality:Speakers should be truthful. They should not say what they think is false, or make statements for which they have no evidence.

- Quantity:A contribution should be as informative as is required for the conversation to proceed. It should be 
neither too little, nor too much. (It is not clear how one can decide what quantity of information satisfies the maxim in a given case.)

- Relevance:Speakers' contributions should relate clearly to the purpose of the exchange.

- Manner:Speakers' contributions should be perspicuous: clear, orderly and brief, avoiding obscurity and ambiguity.

In pragmatic study, it investigates the meaning of words, phrases and full sentences, but unlike semantics which deals with the objective meanings of words that can be found in dictionaries, pragmatics is more concerned with the meanings that words , in fact, convey when they are used, or with intended speaker meaning as it is sometimes referred to. It can be said that pragmaticsattempts to analyze how it happens that often more is communicated than said. If we are to talk about semantics at all therefore, we shall have to identify different kinds of semantics. We can identify, for example, a pragmatic semantics, which studies the meaning of utterances in context: such as in terms of speech acts. We can identify a sentence semantics which studies the meaning of sentences and meaning relations between sentences: this is sometimes described in terms of truth conditions and implicatures, along with the semantics of formal logic (Jackson, 1996: 246).

Based on thebackground above, the writer intends to analyze the pragmatic featurefind in advertisement slogans of motorcycle product. The analysis is based on speech act feature of pragmatics. The study focuses on types of speech acts proposed by john Searl which there are five types of speech acts namely; representation, commissives, directives, declaration, and expressives.Representatives commit a speaker to the truth of an expressed proposition. It can be in forms of asserting,stating, concluding, boasting, describing, and suggesting.Commissivescommit a speaker to some future action. The paradigm of this type emerges in forms of promising, pledging, threatening, vowing, and offering. Directives are used by a speaker who attempts to get the addressee to carry out an action. It can be appear in requesting, advising, commanding, challenging, inviting, daring, and entreating.Declaration affects an immediate change of affairs such as,declaring, baptizing, firing from employment, hiring, and also arresting. Expressives deals with express some sort of psychological state like greeting, thanking, apologizing, complaining, and congratulating.

Thereareseveral previous studies deal with analyzing pragmatic feature of slogans in advertisement. The first previous study was conducted by Eddry(2011)about pragmatic analysis of slogan used in mobile phone brand. His finding from thirty data of mobile brand slogan, there are thirteen data of noun phrase and two verb phrase. Then, there is only one noun clause followed by eleven data of declarative sentence. Finally, there are three data in the form of imperative sentence. The noun phrase is the most preferable slogan used in mobile phone brand. The second previous study was conducted by Chasan (2009) about pragmatic analysis of domestic and international airlines slogan. He found there are three linguistic forms which are found in the domestic and international airlines slogan, namely phrase, clause and sentence. From twenty seven there are fourteen forms of the noun phrase. Then, there is only one independent clause followed by six data of declarative sentence. Finally, there are six data in the form of imperative sentence. The noun phrase is the most preferable slogan used in domestic and international airlines. The third previous study was conducted by Windaryati (2009) about pragmatic analysis of English slogan on soft drink products. The linguistics forms of slogan found in the data are phrase and sentence. Phrase consists of noun phrase and gerund phrase. Meanwhile, the sentence consists of declarative sentence, imperative sentence, and interrogative sentence. From seventeen numbers of data there are five forms of noun phrase, two forms of gerund phrase, five forms of declarative sentence, three forms of imperative and two forms of interrogative sentence. Noun phrase and simple declarative sentence are the most preferable linguistic forms used in 
advertising soft drink products.

\section{METHOD}

In this research, the writer takes descriptive qualitative research. The descriptive qualitative research means a type of research in which it does not include any calculation or enumeration (Moleong, 2004:11). The purpose of the research is to get the systematic description of the facts and the characteristic description of the data.In this research, the researcher chooses slogan used in motorcycle advertisement which uses English slogan as the object of the study. The data are words, phrases, clauses and sentences of motorcycle advertisement slogans. The data sources are from, internet and television. In collecting the data, the writer uses the documentation method. In this research, the data collected by collecting motorcycle advertisement slogans which can be found oninternet and television. The procedures are as follows: finding the data on internet, television; reading the motorcycle advertisement slogan carefully; selecting and writing the slogan into a list of data; coding the data. To analyze the data, the procedures are as follows: displaying the linguistic forms of the slogan used inmotorcycle advertisement by referring linguistic form theory, describing the pragmatic meaning of motorcycleadvertisement slogans by using Speech act theory. And the last is discussing the findings of data analysis, and then drawing the conclusion

\section{RESULTS}

This study used data which were collected from motorcycle advertisement from one brand namely "Honda". This brand was chosen because it could be said that motorcycle with this brand used widely by people around the world including in Indonesia. This motorcycle had many variants in its product and each product had its own slogan. They were 23 slogans found in the advertisements of this brand. Firstly, the data displayed according to the linguistic forms. Secondly, they analyzed based on the type of speech acts which proposed by John Searle. The following were the explanation and the analyzing of the English slogans in motorcycle advertisement based on the data that had been collected.

\section{The Linguistic Forms of the Data}

Table 1: Linguistic Forms of Slogan in Motorcycle Advertisement

\begin{tabular}{|c|c|c|c|}
\hline No & Linguistic Form & Kind & Data \\
\hline 1 & Sentence & Declarative sentence & $\begin{array}{l}\text { Everyone got the beat (r) } \\
\text { I'm Vario } 125 \text { lead the future (c) }\end{array}$ \\
\hline 2 & phrase & Verb phrase & $\begin{array}{l}\text { Excites the world(di) } \\
\text { Ride in pride (r) } \\
\text { Ride the perfection (di) } \\
\text { Ride with pride (r) } \\
\text { Discover great feelings (di) } \\
\text { Live to race (r) } \\
\text { Own the ride (di) } \\
\text { Find new horizon(di) } \\
\text { Unlimit your world(di) }\end{array}$ \\
\hline & & Noun phrase & $\begin{array}{l}\text { One heart (r) } \\
\text { My signature (r) } \\
\text { My brilliant signature(ex) } \\
\text { The talk city ride (r) } \\
\text { Revolution cruiser (r) } \\
\text { The one and only (r) } \\
\text { The Real street fighter (r) } \\
\text { Delight in motion (r) }\end{array}$ \\
\hline
\end{tabular}




\begin{tabular}{|l|l|l|}
\hline \multicolumn{2}{|c|}{ Table 1:Contd., } \\
\hline & & \multicolumn{1}{|c|}{} \\
& Adjective phrase & $\begin{array}{l}\text { Unbeatable you (r) } \\
\text { Uniquely happy (r) } \\
\text { Your powerful style (r) } \\
\text { Total control (r) }\end{array}$ \\
\hline
\end{tabular}

According to the data which displayed on table 1, it could be seen that from 23 English slogans in motorcycle advertisement that had been collected, they had two kinds of linguistic forms namely sentence and phrase. They consisted of two sentences and twenty-one phrases. All of the sentences in the data performed in declarative sentences. In addition, there was three kinds of phrases emerged in the data collected. They appeared in nine verb phrases, eight noun phrases, and four adjective phrases.

\section{Speech Acts Type of Slogan in Motorcycle Advertisement}

As stated in the previous part of this article, the analysis of the data found is based on speech act type suggested by John Searle. They are representatives, commissives, directives, declaration, and expressives.

Representatives (Asserting, Stating, Concluding, Boasting, Describing, and Suggesting)

Based on the data found it could be analyzed that there was several slogans' utterance included in this type. There were fifteen utterances belonged to this type of speech act. They were as following;

- Everyone got the beat- The talk city ride

- $\quad$ Ride in pride- Revolution cruiser

- $\quad$ Ride with pride- The one and only

- Live to race- The Real street fighter

- One heart- Delight in motion

- My signature- Your powerful style

- Unbeatable you- Total control

- Uniquely happy

Those all utterances above belonged to representatives type because all of them deal with the truth of an expressed proposition. Most of those utterances were in form of stating.

\section{Commisives}

It commits a speaker to some future action. This study found that there was only one sentences belong to this type. It was the utterance of "I'm Vario 125 lead the future".

\section{Directives}

Directives type relates to the effort of speaker that the hearer will do certain action after hearing the utterance.It was found that six slogans' utterances in motorcycle advertisement included in directives type. They were Excites the world, Ride the perfection, Discover great feelings, Own the ride, Find new horizon, and Unlimited your world. 


\section{Expressives}

Expressives deal with express some sort of psychological state like greeting, thanking, apologizing, complaining, and congratulating. This study found only one slogan belonged this speech acts type. The utterance "My brilliant signature" expressed the feeling of praising to the product offered.

According to the data found there were no slogans that belonged to declaratives type of speech acts.

\section{Conversational Maxim}

This study analysis based on four conversational maxims that called as Grice's maxim. They were maxim of quantity, maxim of quality,a maxim of relation and themaxim of manner. According to the writer since these slogans emerged in the advertisement which it was no real conversational circumstances so it would be very hard to precisely analyze the utterance through the four maxims proposed. Therefore, this study analyzed the maxim of the slogans based on the utterance appeared. Since the purpose of the slogans was to persuade the audiences in this context were the consumers or buyers so they used to inform about the product offered and at the same time they persuade the audience as id that what they had said in slogans were tell the truth about the product. Therefore all slogans could be included in quantity and quality maxim at once.

\section{DISCUSSIONS}

Based on the findings of the study, there are several interesting findings which can be discussed. All of the English slogans used in the advertisement are using interesting or persuasive utterances. Of course, this is done because the intention or purpose of the advertisement and the slogan itself are to persuade the people to buy the products offered in the advertisements.

The English slogans that used in motorcycle advertisement are mostly displayed in the form of phrases rather than in sentence form. It can be seen that from 23 slogans collected consist of two sentences and twenty-one phrases. It may be inferred that the use of phrases seems more effective than the use of sentences.It seems almost similar to the study conducted by Eddry (2011) he found the slogans in mobile phone consisted of phrases and sentences There are three phrases found in this study, verb phrases, noun phrases, and adjectives phrases. The use of verb and noun phrases almost the same. The finding of this studymay quite similar to the result of a study conducted by Windaryati (2009) her study found that slogans in soft drink product speared in the forms of sentence and phrase. On the other side, this study results a little bit different from the study conducted by Inderagiri (2013), he analyzed pragmatics feature of slogans in car advertisements. He found that the slogans not only emerged in sentences or phrases but also words.

Furthermore, the analysis of speech acts types of this study shows that almost types proposed by John Searle are used in the slogans. Fifteen slogans belong to representative's types, six slogans belong to directives, and commisives and expressives types share the same amount of phrase, one phrase includes in commisives and the rest one goes to expressives. There is only directives type that not found in this study based on the data collected. But it doesn't mean that there is no slogan in advertisement uses directives type of speech acts. It is very possible that in another kind of advertisements there is slogan belongs to directives type of speech acts.

The interesting one of the findings from this study that based on the conversational maxim, all of the slogans belong to quantity and quality maxims. As explained in the result section, that the analysis of conversational maxims only 
be based on their real utterances.It happens because all of the slogans are used to persuade the consumers or buyers, therefore they are so informative, that is why they belong to quantity maxims and all of slogans try to tell the truth therefore they include in quality maxim.

\section{CONCLUSIONS}

In conclusion, language application area is not only in a conversation class. There are some environments or field where the language usually practices. For example, there are languages for business, language for politics, language for entertainment, language for advertisement, etc. Each of them has its own characteristics. Such as in the language of advertisement, it must be simple, interesting and easy to be understood. An interesting advertisement will influence the customer to use the product or to do what the advertisement required. Easy to be understood means that the society is able to know what product promotes in it, what for it is used. So there is a communication between the advertiser and the public. The slogans which are used also play role in attracting the consumers or buyers.

The English slogans found in the Honda motorcycle advertisements show that the appropriate use of the language is very important. They use phrase and sentences that can attract the audiences. In slogans are also have pragmatics meaning even though they are only analyzed based on speech acts theory and conversational maxim. It is very possible if the slogans are analyzed through another feature of pragmatics such as deixis, politeness, implicature and etc. it reveals more interesting things behind the use of English slogans in certain product advertisements

In short, this study seems not sufficient in analyzed the pragmatics feature in slogans of advertisement. Therefore others studies can be conducted in analyzing pragmatic of English slogans in advertisements through another feature of pragmatics.

\section{ACKNOWLEDGMENT}

This research was supported by Indonesia Endowment Fund for Education (LPDP) scholarship. My gratitude to LPDP that recently funds my master degree study at UniversitasPendidikan Indonesia.

\section{REFERENCES}

1. Chasan, Nur. 2009. A Pragmatic Study on Domestic and International Airlines Slogan. Surakarta: Muhammadiyah University.

2. Eddry Y, Phengky. 2011. A Pragmatic Analysis of Slogan Used in Mobile Phone Brand. Surakarta: Muhammadiyah University.

3. Gregory, H. 2000. Semantics. London: Routledge.

4. Grice, H.P. 1989.Studies in the Way of Words.Harvard University Press.

5. Hofmann, Th. R. 1993. Realms of Meaning.An Introduction to Semantics. New York: Longman Publishing.

6. Inderagiri, Ashar Waskito (2013) A Pragmatic Analysis Of Slogan Used In Car Advertisement. Skripsi thesis, Universitas Muhammadiyah Surakarta.

7. Jackson, H. 1988. Words and Their Meaning. New York: Longman.

8. Datta, Veto, and S. Vasantha. "Positioning of a Brand Through Advertising and Impact of Advertisement on Customers Preference." 
9. Kuzairi, 2016. Language Of Advertisement: A Pragmatic View. Stilistika: JurnalBahasa, Sastra, danPengajarannyaISSN 2527-4104 1(2)

10. Ajay, Vasanthi, and SoumyaManjunathChavan. "Stereotype and Culture in Indian Advertisements."

11. Leech, G. 1983.Principles of Pragmatics. London: Longman.

12. Levinson, S. 1983.Pragmatics. Cambridge: Cambridge University Press.

13. Mey, J.L. 1994. Pragmatics.An Introduction. Cambridge: Blackwell Publishers.

14. Moloeng, Lexy. 1989. MetodologypenelitianKualitatif. Jakarta: Depdikbud.

15. Thomas, J. 1995. Meaning in Interaction: An Introduction to Pragmatics. London: Longman.

16. Urdang, Laurence and Ceila Dame Robbins. 1984. Slogans. USA: Gale Research Company.

17. Verschueren, J. 1999. Understanding Pragmatics. London: Arnold.

18. Windaryati, Esti. 2009. A Pragmatic Analysis of English Slogan on Soft Drink Products. Surakarta: Muhammadiyah University.

19. Yule, G. 1996. Pragmatics. Oxford: Oxford University Press. 
